\title{
Body size, loading capacity and rate of reproduction in the communal bee Andrena agilissima (Hymenoptera; Andrenidae) ${ }^{1}$
}

\author{
Manuela GiovanetTI ${ }^{a *}$, Eloisa LASSo ${ }^{\text {b** }}$ \\ a Dip. Biologia, Università degli Studi di Milano, Via Celoria 26, 20133 Milano, Italy \\ b Dep. Plant Biology, University of Illinois, 505 S. Goodwin Av., 265 Morrill Hall, Urbana, IL 61801, USA
}

Received 12 February 2004 - revised 3 November 2004 - accepted 12 November 2004

Published online 9 August 2005

\begin{abstract}
In bees, body size may be particularly important in determining the loading capacity, and consequently the rate of reproduction. We studied a population of Andrena agilissima (Hymenoptera: Andrenidae) in Italy, weighing provisioning females, load being carried and pollen provisions. We found no correlation between adult body size and loading capacity. Weight of pollen collected per trip did not vary across the day, while weight of nectar collected increased in the afternoon. The amount of nectar being carried was independent of the amount of pollen. The A. agilissima rate of reproduction resulted in less than 1 provision mass produced per day (3.6 offspring/female per season). This result is consistent with observations in other Andrena species which suggests a phylogenetic constraint in the rate of reproduction that merits further study.
\end{abstract}

body size / loading capacity / Andrenidae / rate of reproduction / pollen / nectar

\section{INTRODUCTION}

Body size is often related to fitness. In Hymenoptera (bees, wasps and ants), several studies have documented that larger individuals are more successful in establishing mating territories (O'Neil, 1983; Sugiura, 1991; Coelho and Holliday, 2001), have higher fecundity and larger offspring. On the other hand, other studies have not found positive correlations between provisioner body size and fecundity (Frohlich and Tepedino, 1986; Johnson, 1990; Field, 1996). Often body size is related to foraging ability (Johnson, 1990; Stout, 2000).

Foraging efficiency and loading capacity of a given female are factors limiting its provisioning (the amount of provisions left in a brood cell for the complete development of the larva) and consequently the number of offspring it can produce during its life time. Larger females may be more efficient foragers because they can fly faster and visit more flowers per unit time (Pyke, 1978), and they can transport larger pollen and nectar loads in each excursion (Klostermeyer et al., 1973). Loading capacity is a potential trait under selection since it is directly related to fitness.

The reproductive biology of solitary and presocial ground-nesting bees in the family Andrenidae has been studied for some species, but only a few studies have looked at the relation between foraging ability and rates of reproduction (Danforth, 1990; Visscher and Danforth, 1993). However, none of the existing studies

* Corresponding author: manuela.giovanetti@ unimi.it

**elasso@students.uiuc.edu

${ }^{1}$ Manuscript editor: Jean-Noël Tasei 
have also included measures of the nectar load, even though nectar may be an important component of the provision masses and may impose a limitation on the size of the load carried per trip.

Some Andrenidae species show very low rates of reproduction, often less than a cell per day (Andrena barbilabris, Witt, 1992; Calliopsis pugionis, Visscher and Danforth, 1993; Andrena rudbeckiae, Neff and Simpson, 1997). The highest average rate published for Andrenidae is 4 cells per day (range 1-6, Calliopsis persimilis; Danforth, 1990).

A cell must be constructed, provisioned through a certain number of foraging trips, and closed. Concerning the number of trips required for a cell, many elements need to be considered: the gender of the offspring in sexually dimorphic species, and/or the quality of the mother and her ability to collect food.

Andrena agilissima (Scopoli) is a groundnesting, oligolectic bee with pre-social behaviour (Westrich, 1989). Females nest communally in aggregations and share entrances to subterranean nests on sloped or vertical earth walls (Giovanetti et al., 1999, 2003). At the beginning of their active season (spring), females emerge and start digging their subterranean cells, usually reusing old tunnels. During the day, each female makes foraging trips on Brassicaceae and collect pollen and nectar mainly from flowers of Raphanus raphanistrum and Sinapis arvensis (Giovanetti and Papadia, unpublished data). Andrena females carry pollen on the hind tibia, densely clothed with hairs that form a large pollen-carrying brush; on the hind femora, mainly on the front and lower surface in a basket-like structure; and on the trochanter, that carries a group of long hairs forming another basket, the floccus. Nectar is transported to the nest internally in the crop, as in other bees, and may be used to moisten pollen transported on the legs (Proctor et al., 1996), added to the pollen mass stored in the cell and eaten by adult individuals.

In this work we present quantitative data on: (a) females body weight variability, (b) the load weight females carry to the nest and (c) the temporal changes in pollen and nectar load during the day. Furthermore, since for A. agilissima the average number of trips a female makes daily is known (Giovanetti, unpublished data), we were able to calculate the rate of reproduction (number of cells completed per day) for this species. To do so we collected and weighed provision masses found in cells and estimated the number of loads needed to complete a provision mass.

\section{MATERIALS AND METHODS}

\subsection{Study area and data collection}

The study area was located on the Isola d'Elba (Tuscany, Italy; $10^{\circ} \mathrm{E}, 43^{\circ} \mathrm{N}$ ). For detailed information on the bee aggregation, see Giovanetti et al. (1999). The main data collection was carried out from 16th to 22nd of May 2000, while provision mass weights and nectar concentrations were measured in 2000 and 2002.

\subsection{Bee weight and load weight}

A total of 192 bees was collected and weighed while leaving or returning to the nest between 09:00 and 17:00 (solar hour). Bees were first immobilized by putting them in glass cups into a cooler with ice for circa $5 \mathrm{~min}$. Afterward we were able to transfer the bee to an empty capsule (transparent medical pill), preventing her from moving and consequently losing pollen grains. After weighing the bee plus its load (with a digital balance; precision: $0.001 \mathrm{~g}$ ), we transferred it to a shaded box for about 20-30 min, where the bee cleaned itself from any pollen grains. Then bees were checked for the presence or absence of nectar in the crop by gently pressing the abdomen and collecting the regurgitated nectar with $10 \mu \mathrm{L}$ microtubes (Kearns and Inouye, 1993; Stone 1995). Subsequently, we re-weighed the bee without any load. The nectar weight was estimated from its volume by using a regression equation obtained from weighing a series of known volumes of nectar (weight $=-0.2953+[1.2851 \times$ volume $] ; \mathrm{r}^{2}=0.8534$; $\mathrm{F}=69.84 ; P=0.0001 ; \mathrm{n}=14)$. The sugar concentration in nectar transported by the bees was also measured using a refractometer (range: $0-80$ on a BRIX scale, mg sugar / mg solution).

\subsection{Weight of brood provision mass}

Provisions appear to be a mixture of pollen and nectar elaborated to form a compact ball. In 2000 we found a total of 24 masses, 9 of them intact and 15 partially consumed. All masses were weighed when fresh and after being dried at $50{ }^{\circ} \mathrm{C}$ for $60 \mathrm{~h}$. From the regression equation between fresh and dry weight $($ fresh weight $=32.115+[1.0834 \times$ dry 


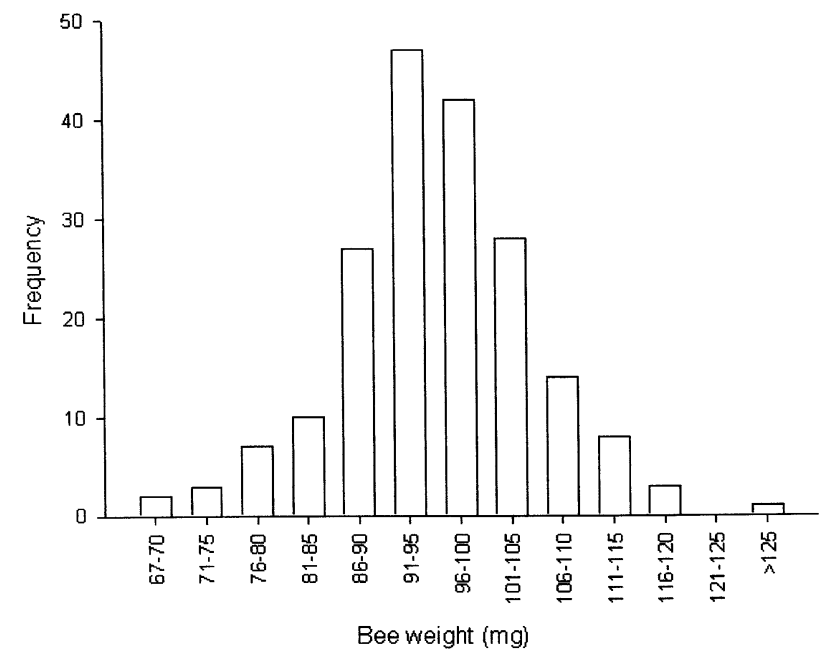

Figure 1. Female size distribution in Andrena agilissima $(\mathrm{n}=192)$ on Isola d'Elba, Italy. Size is in fresh weight $(\mathrm{mg})$. weight]; $\mathrm{r}^{2}=0.86 ; \mathrm{F}=31.1 ; P=0.0001 ; \mathrm{n}=24$ ) we were able to use also data from 1998 of intact dry provision masses. In May 2002, 10 more intact masses were obtained from nests and weighed while fresh. To obtain fresh weight distribution of provision masses we used only data of the intact ones (7 masses collected in 1998; 9 masses in 2000; 10 masses in 2002). The mean rate of reproduction of this population (putative number of offspring produced) was calculated by dividing the average number of trips in a season (estimated from 121 individually marked bees; Giovanetti, unpublished data) by the number of trips that are needed to provision a cell, given the mean loading capacity of a bee estimated in this study.

\section{RESULTS}

\subsection{Bee weight and load weight}

Female size in the population studied appeared to have a normal distribution (Fig. 1). Female fresh weights ranged from 67 to $127 \mathrm{mg}$, with $95.75 \mathrm{mg}$ the mean weight (Tab. I). However, despite the variability in female size, there was no correlation between bee weight and the load a female transported (Fig. $2 ; \mathrm{r}^{2}=0.014 ; \mathrm{F}=$ $1.59 ; P=0.21 ; \mathrm{n}=117)$. The load varied between the $6.3 \%$ and the $37.5 \%$ of the bee weight.

No correlation was found between the amount of nectar and pollen being transported in the same load $\left(\mathrm{r}^{2}=-0,004 ; \mathrm{F}=0.51 ; P=0.47\right.$;
Table I. Descriptive statistic of females, pollen and nectar loads, cell provisions.

\begin{tabular}{lcccc}
\hline & $\begin{array}{c}\text { Mean fresh } \\
\text { weight } \\
(\mathrm{mg})\end{array}$ & $\begin{array}{c}\text { SD } \\
(\mathrm{mg})\end{array}$ & $\begin{array}{c}\text { Range } \\
(\mathrm{mg})\end{array}$ & $\mathrm{N}$ \\
\hline Bee weight (female) & 95.7 & 9.4 & $67-127$ & 192 \\
$\begin{array}{l}\text { Total load (pollen } \\
\text { and nectar) }\end{array}$ & 16.8 & 0.6 & $7-35$ & 117 \\
$\begin{array}{l}\text { Pollen load } \\
\text { Nectar load }\end{array}$ & 13.3 & 0.4 & $2-34$ & 117 \\
Provision mass & 3.5 & 0.4 & $0-19$ & 117 \\
\hline
\end{tabular}

$\mathrm{n}=117$ ), indicating that the amount of nectar being transported is not dependent on the amount of pollen being transported, and vice versa.

The mean load of pollen carried at each hour was fairly constant during the entire day (Spearman: 0.357; n.s.; Fig. 3), while the nectar transportation was strictly related to the time of the day (Spearman: 0.929; $P=0.01$; Fig. 3). Nectar load size increased in the afternoon. The same is true when considering the number of bees carrying nectar, which increased with time of day (Spearman: $0.714 ; P=0.05$; Fig. 3). In the morning we found only $2-12 \%$ of the collected bees with nectar, while after 13:00 h around 45-89\% of bees collected per day were carrying nectar in their crops. The sugar 


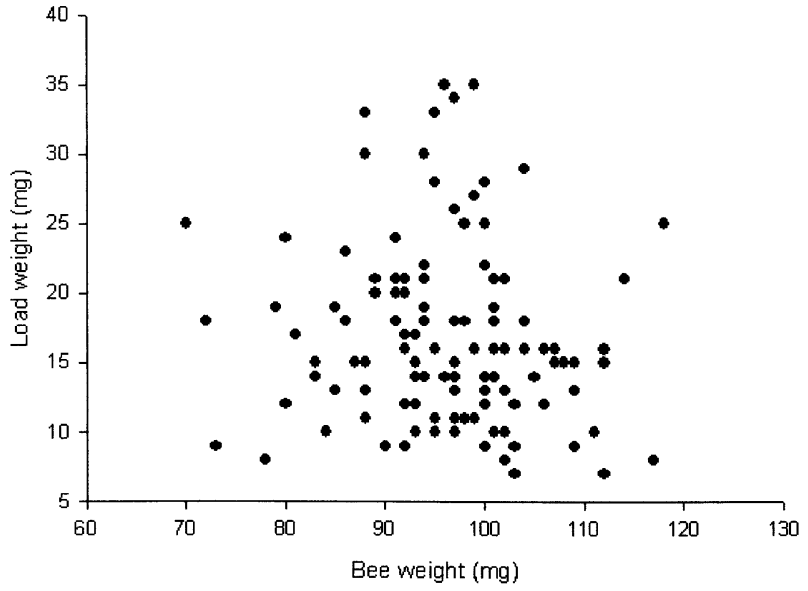

Figure 2. Relationship between Andrena agilissima female body size and total load (pollen and nectar) transported to the nest during each trip $(n=117)$. Size is in fresh weight $(\mathrm{mg})$.

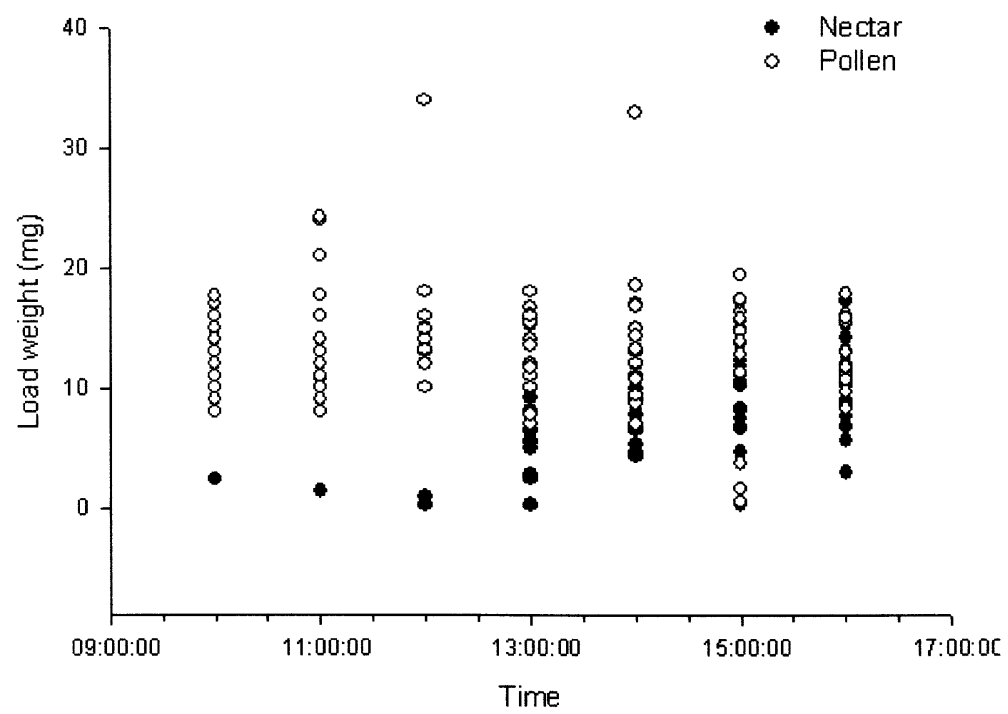

Figure 3. Daily variation in the type of load $(n=117)$ carried to the nest by Andrena agilissima females on Isola d'Elba, Italy. White dots represent pollen loads, while dark dots represent nectar loads.

concentration in bee crops increased with the time of the day $\left(\mathrm{r}^{2}=0.34 ; \mathrm{F}=65.8\right.$, d.f. $=1, P<$ 0.001; Fig. 4).

\subsection{Provision mass and rate of reproduction}

The fresh weight distribution of provision mass was normally distributed (KolmogorovSmirnov test for normality; $\mathrm{D}=0.13, P=0.15$, Fig. 5). Provision mass size ranged from 133 to 220 mg (Tab. I; Fig. 5).
From data previously collected in 1997 (from April to June, during the entire season of activity) on 121 individually marked females, we know that a bee typically makes 2.4 trips per day $(\mathrm{SD}=1.9$; range: $1.0-15.0)$. However, all bees showed one or more days of outside-inactivity (no trips at all; possibly digging inside the nest), despite favourable weather conditions and often made $1-2$ trips per day $(65.2 \%$ of 1441 trips). The 121 marked bees were alive from 7 to 30 days and were active (foraging) on average 16 days ( $\mathrm{SD}=6$; range 4-30 days). 


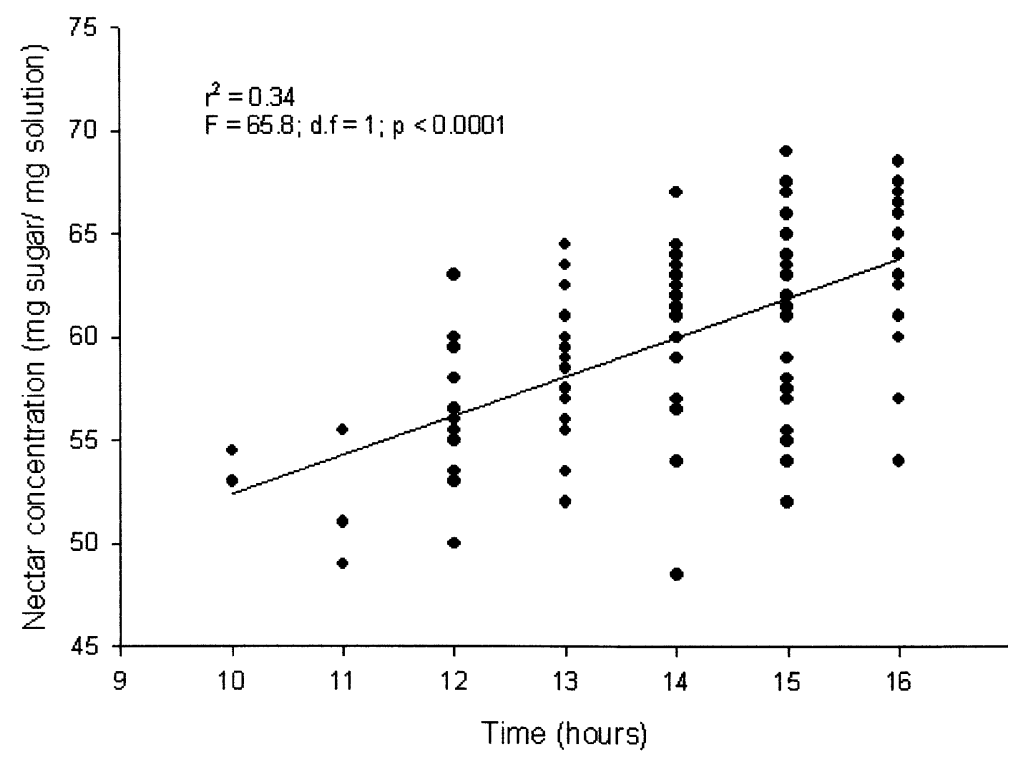

Figure 4. Daily variation in the sugar concentration of the nectar load carried to the nest by Andrena agilissima females on Isola d'Elba, Italy $(n=129)$.

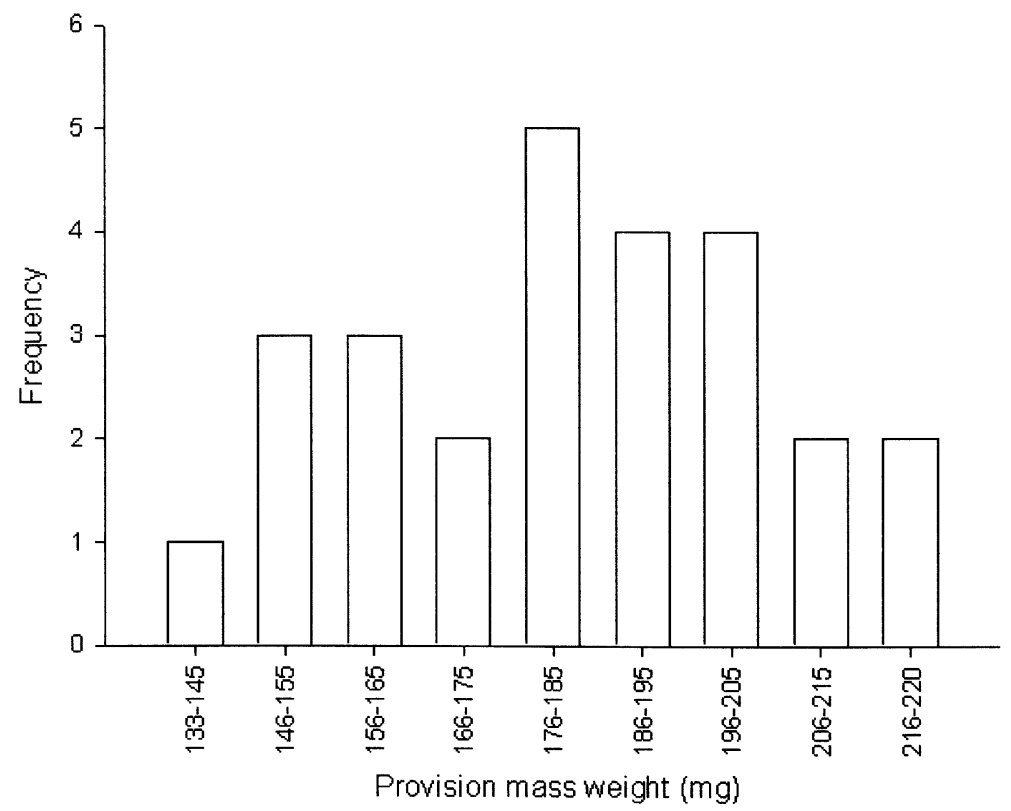

Figure 5. Size distribution of the pollen mass provisioning for the larva found in cells within the nest of Andrena agilissima on Isola d'Elba, Italy $(\mathrm{n}=26)$. They are represented as fresh weight. 
Considering that $16.8 \mathrm{mg}$ is the mean total load a bee carries per trip (range 7-35 mg; Tab. I), we infer that to complete the smallest provision mass (133 mg) a bee should accomplish approximately 8 trips (range 4-19 trips), whereas for the biggest provision mass $(220 \mathrm{mg})$ it will need around 13 trips (range 6-31 trips). Therefore, an average bee that is active for 16 days and carries 2.4 trips per day will be able to complete around 4.8 of the smallest provision mass or 2.9 of the biggest provision mass during its lifetime. If we consider an average provision mass $(181.9 \mathrm{mg})$, then we obtain 3.6 offsprings/female per season.

\section{DISCUSSION}

In A. agilissima body size is not correlated with loading capacity (Fig. 2), which differs from what has been found in other studies. Klostermeyer et al. (1973) found that larger females of Megachile rotundata Fabricius (a solitary bee of the family Megachilidae) transported larger pollen and nectar loads in each excursion than smaller females. In contrast, Ramalho et al. (1998) observed a decrease in pollen load capacity with increased body size in Melipona quadrifasciata Lepeletier (Apidae), apparently due to allometric variation of the corbicula (the pollen carrying structure on the hind tibia). The pollen load of A. agilissima is fairly constant and independent from the amount of nectar that a bee may carry. Reasons for this might be limited transport ability based on the amount of pollen that may be accumulated on the hind legs, or that pollen handling time is limiting. It is possible that other morphological traits such as hind tibia length or density of scopal hairs will be related to loading capacity.

A. agilissima carrying capacity varied between 6.3 and $37.5 \%$ of its fresh body weight. Similar results have been found for a congener, Andrena rudbeckiae, which is able to carry up to $10.5 \%$ of its fresh weight and also completes less than one cell per day (Neff and Simpson, 1997). In contrast, Danforth (1991) found that Perdita portalis Timberlake carried $68 \%$ of its dry weight, and is able to provision one cell per day (Tab. II). Carrying capacity is related to the number of cells that can be provisioned per day

Table II. Review of traits related to the rate of reproduction of Andrenidae species.

\begin{tabular}{|c|c|c|c|c|c|}
\hline Species & $\begin{array}{c}\text { Trips/ } \\
\text { day }\end{array}$ & $\begin{array}{l}\text { N. of } \\
\text { trips/cell }\end{array}$ & $\begin{array}{c}\text { Average n. of } \\
\text { cell/ } \\
\text { day }\end{array}$ & $\begin{array}{c}\text { Average n. of } \\
\text { offspring/ } \\
\text { female }\end{array}$ & Reference \\
\hline Andrena agilissima & 2.4 & $8-13$ & $<1$ & 3.6 & This paper \\
\hline Andrena barbilabris & $3-6$ & $5-8$ & $<1$ & - & Witt, 1992 \\
\hline Andrena cineraria & $3-4$ & $6-10$ & $<1$ & - & Gebhardt and Röhr, 1987 \\
\hline Andrena clarkella & $3-4$ & $8-12$ & $<1$ & - & Gebhardt and Röhr, 1987 \\
\hline Andrena erythrogaster & $1-7$ & - & $<1$ & - & Miliczky, 1988 \\
\hline Andrena erythronii & $1-2$ & - & - & - & Michener and Rettenmeyer, 1956 \\
\hline Andrena flavipes & 6 & $12-14$ & $<1$ & - & Gebhardt and Röhr, 1987 \\
\hline Andrena fulva & - & - & $<1$ & 2.38 & Paxton, pers. comm. \\
\hline Andrena fuscipes & $3-4$ & 6 & $<1$ & - & Gebhardt and Röhr, 1987 \\
\hline Andrena nycthemera & $1-6$ & - & - & - & Schönitzer and Klinksik, 1990 \\
\hline Andrena rudbeckiae & $6-8$ & $\begin{array}{c}\text { Male: } 6-7 \\
\text { Female: } 13-15\end{array}$ & $\begin{array}{c}1 \\
<1\end{array}$ & - & Neff and Simpson, 1997 \\
\hline Andrena vaga & - & - & $<1$ & 3.49 & Paxton, pers. comm. \\
\hline Calliopsis persimilis & - & - & 4 & - & Danforth, 1990 \\
\hline Calliopsis pugionis & $3-6$ & - & 1 & - & Visscher and Danforth, 1993 \\
\hline Perdita portalis & - & - & 1 & - & Danforth, 1991 \\
\hline
\end{tabular}


and, as a consequence, to the rate of reproduction. This close similarity within the genus Andrena (Tab. II) may indicate that some shared character related to foraging efficiency or loading capacity restricts the load of pollen and nectar that can be transported per unit time. Alternatively, the unstable weather conditions typical for early springtime may affect the daily activity of females, reducing the total number of foraging flights (A. regularis, Schrader and LaBerge, 1978; A. erythrogaster, Miliczky, 1988; A. nycthemera, Schönitzer and Klinksik, 1990). This hypothesis is especially relevant when considered that the majority of Andrena, showing low rates of reproduction, are early springtime species which are alive for 30-40 days but not foraging every day (Schönitzer and Klinksik, 1990). A strong influence of the weather conditions (cloudy days, rainy days, sudden drop in the temperature) was also suggested as a factor favouring the evolution of adaptive behaviours such as the time spent at the nest entrance before leaving the nest in the morning (Miliczky, 1988; Schönitzer and Klinksik, 1990).

Nectar and pollen collection by A. agilissima had different diurnal patterns (Fig. 3). Pollen collection occurred throughout the day, while nectar collection occurred mainly in the afternoon. Although pollen collection patterns may differ among species, it seems that nectar collection tends to be restricted to the afternoon. Other bees show peaks of pollen collection mostly in the morning, while nectar collection peaked later in the day (Roubik, 1989), often related to a higher sugar concentration (Rust et al., 2003) and feeding needs. Neff and Simpson (1997) found that the Andrena rudbeckiae diurnal provisioning peak corresponded to the peak of pollen presentation by flowers. Also, because sugar concentration in nectar tends to increase across the day (Roubik and Buchmann, 1984), it is likely that bees search for nectar resources later in the day in order to increase the caloric content of the pollen mass that will feed the larvae. This is further supported by the increase in sugar concentration with time observed on the nectar measured in returning bees during this study.

Even though adult individuals of A. agilissima show sexual dimorphism, where females had wider heads than males (Paxton et al., 1999), we found that the provision weight for the larvae was normally distributed. Schrader and LaBerge (1978) observed a similar result for another species, Andrena regularis. However, the high frequency (69\%) of provision masses weighing more than $176 \mathrm{mg}$ (Fig. 5) may support Paxton et al. (1999) finding that in this population the sex ratio at emergence is female biased (females are the heavy sex and heavy provisions are likely to be for them).

The fact that all species within the genus Andrena studied to date exhibit a low rate of reproduction $(<1$ cell per day) whereas species in a closely related genus can produce 1 to 6 cells per day (Tab. II), suggests that there may be a phylogenetic constraint on the rate of reproduction in Andrena. More data on morphological traits, loading capacity and rate of reproduction, as well as ecological comparisons within Andrenidae are needed to explore further this possibility. Such types of analyses may help to clarify the reasons behind species differences in loading capacity and rate of reproduction.

\section{AKNOWLEDGEMENTS}

We thanks Parco dell'Arcipelago Toscano, Marta and Stani for the accommodation, and Erboristeria "Natura e Salute" for providing some important supplies. We are indebted to E. Scamoni, B. Scanni, C. Polidori, C. Papadia and F. Torres for their contribution; to F. Andrietti and J.D. Asis for comments on the first draft of the paper; to R.J. Paxton for revision and data comparison. We are especially indebted to three anonimous referees for their valuable suggestions. This study was supported by an one-year grant (Young Researchers-University of Milan) to Dr. Giovanetti.

Résumé - Taille corporelle, capacité de chargement et taux de reproduction chez l'abeille Andrena agilissima (Hymenoptera, Andrenidae). Le but de cette étude était d'étudier la relation entre la taille corporelle et la capacité de chargement d'une abeille oligolectique, Andrena agilissima Scopoli, les résultats des études antérieures étant contradictoires. Nous avons pesé 192 femelles qui rentraient au nid et retiré leurs deux charges (nectar et pollen), qui ont été ensuite pesées séparément. Nous avons également pesé les provisions $(n=26)$ déposées par les abeilles dans leur nid.

Le poids des abeilles a varié de 67 à 127 mg (Fig. 1 ; Tab. I) mais, chez cette espèce, la taille corporelle n'est pas corrélée à la capacité de chargement (Fig. 2). La charge moyenne de pollen transportée par heure n'a pas varié au cours de la journée, tandis que le transport de nectar était strictement lié au 
moment de la journée (Fig. 3). Le nombre d'abeilles transportant du nectar a augmenté l'après-midi. La concentration en sucres de nectar dans le jabot a augmenté au cours de la journée (Fig. 4). Aucune corrélation n'a été trouvée entre les quantités de nectar et de pollen transportées au cours d'un même voyage. Le taux de reproduction d'A. agilissima a été de 3,6 par femelle et par saison.

La capacité de transport peut être limitée par la quantité de pollen susceptible d'être accumulée sur les pattes postérieures. La variation dans le temps de la récolte de pollen et de nectar peut être liée à leur disponibilité dans les fleurs. Puisque la concentration en sucres du nectar tend à augmenter au cours de la journée, il est probable que les abeilles recherchent les sources de nectar plus tard dans la journée afin d'augmenter la teneur calorique des provisions pour les larves. La capacité de chargement est liée au nombre de cellules approvisionnées par jour et, en conséquence, au taux de reproduction. Des résultats similaires ont été trouvés pour d'autres espèces du même genre (Tab. II). Cette similitude peut indiquer qu'il existe au sein du genre des caractères qui peuvent restreindre les charges de pollen et de nectar transportées. Les conditions météorologiques instables typiques du début du printemps peuvent affecter l'activité journalière des femelles en réduisant le nombre de vols de butinage et, en conséquence, la descendance produite. Cette hypothèse est particulièrement intéressante si l'on considère que de nombreuses espèces d'andrènes ayant un taux de reproduction bas sont en fait des espèces du début du printemps.

Andrenidae / taille corporelle / capacité de chargement / taux de reproduction / pollen / nectar

Zusammenfassung - Körpergröße, Sammelkapazität und Vermehrungsrate bei der gesellig nistenden Biene Andrena agilissima (Hymenoptera; Andrenidae). Die Beziehung von Körpergröße und Sammelkapazität wurde bei der oligolektischen Biene, A. agilissima (Hymenoptera; Andrenidae) untersucht. Frühere Untersuchungen ergaben widersprüchliche Ergebnisse, sodass die Erhebung zusätzlicher Daten nötig war. Die Gattung Andrena mit ihren vielen Arten ist für diese Teste sehr geeignet. Pollen wird an den Hinterbeinen, Nektar im Honigmagen transportiert. Von 192 zum Nest zurückkehrenden Weibchen wurden Nektar- und Pollenladungen abgetrennt und das Gewicht des Weibchens sowie das der Ladungen getrennt bestimmt. Wir wogen auch die Vorratsmenge in den Nestern (26 intakte Zellvorräte). Die Untersuchungen wurden im Mai 2000 und 2002 in Italien (Isola d'Elba, Joskana) durchgeführt.

Das Gewicht der Bienen schwankte zwischen 67127 mg (Abb. 1; Tab. I), aber Körpergewicht und Menge der Ladung sind voneinander unabhängig (Abb. 2). Die mittlere Pollenmenge pro Stunde änderte sich während eines Tages nicht im Gegensatz zur Nektarmenge, die deutlich von der Tageszeit abhing (Abb. 3). Sowohl das Nektargewicht pro Biene als auch der Anteil der Nektarsammlerinnen nahm nachmittags zu. Die Zuckerkonzentration im Magen stieg ebenfalls im Tagesverlauf an (Abb. 4). Es gab keine Korrelation zwischen Nektar- und Pollenmenge bei gleichzeitiger Sammlung. Die Reproduktionsrate dieser Art beträgt 3.6 Nachkommen/ Weibchen in einer Saison.

Individuelle Größenunterschiede bei A. agilissima haben keinen Einfluss auf die Sammelkapazität der Weibchen. Die Pollenladungen sind konstant und unabhängig von der Nektarmenge. Der Pollentransport könnte durch die Fassungskapazität der Hinterbeine begrenzt sein. Die zeitlichen Unterschiede beim Pollen- und Nektarsammeln könnten dagegen vom Angebot der Pflanzen abhängen. Die Zunahme der Zuckerkonzentration im Nektar während des Tagesverlaufs deutet darauf hin, dass die Bienen aus diesem Grund später vermehrt Nektar suchen.

Die Sammelkapazität korreliert mit der Zellenzahl, die pro Tag verproviantiert werden, und damit auch mit der Reproduktionsrate. Ähnliche Ergebnisse wurden auch für andere Arten dieser Gattung beschrieben (Tab. II). Diese Ähnlichkeit könnte darauf deuten, dass es in der Gattung einige gemeinsame Eigenschaften gibt, die die Sammelkapazität von Pollen und Nektar begrenzen. Alternativ könnte das unbeständige Wetter, typisch für den Beginn des Frühjahrs, die Aktivität der Weibchen durch die Reduzierung der Zahl der Trachtflüge und als Konsequenz die Zahl der Nachkommen beeinflussen. Diese Hypothese ist unter dem Aspekt, dass viele Andrena Arten mit geringen Reproduktionsraten im frühen Frühjahr auftreten, besonders interessant.

Köpergröße / Sammelkapazität / Andrenidae / Reproduktionsrate / Pollen / Nektar

\section{REFERENCES}

Coelho J.R., Holliday C.W. (2001) Effects of size and flight performance on intermale mate competition in the cicada killer, Sphecius speciosus (Hymenoptera: Sphecidae), J. Insect Behav. 14, 345-351.

Danforth B.N. (1990) Provisioning behavior and the estimation of investment ratios in a solitary bee, Calliopsis (Hypomacrotera) persimilis (Cockrell) (Hymenoptera: Andrenidae), Behav. Ecol. Sociobiol. 27, 159-168.

Danforth B.N. (1991) Female foraging and intranest behavior of a communal bee, Perdita portalis (Hymenoptera, Andrenidae), Ann. Entomol. Soc. Am. 84, 537-548.

Field J. (1996) Patterns of provisioning and iteroparity in a solitary halictine bee, Lasioglossum (Evylaeus) fratellum (Perez), with notes on $L$. $(E$. 
calceatum (Scop.) and L. (E.) villosulum (K.), Insectes Soc. 43, 167-182.

Frohlich D.R., Tepedino V.J. (1986) Sex ratio, parental investment, and interparental variability in nesting success in a solitary bee, Evolution 40, 142-151.

Gebhardt M., Röhr G. (1987) Zur Bionomie der Sandbienen Andrena clarkella (Kirby), A. cineraria (L.), A. fuscipes (Kirby) und ihrer Kuckucksbienen (Hymenoptera: Apoidea), Drosera 87, 89114.

Giovanetti M., Andrietti F., Martinoli A., Rigato F. (1999) Evidence of entrance sharing and subterranean connections in Andrena agilissima (Hymenoptera, Andrenidae), J. Insect Behav. 12, 423-431.

Giovanetti M., Scamoni E., Andrietti F. (2003) The multi-entrance system in an aggregation of Andrena agilissima (Hymenoptera; Andrenidae), Ethol. Ecol. Evol. 15, 1-18.

Johnson M.D. (1990) Female size and fecundity in the small carpenter bee, Ceratina calcarata (Robertson) (Hymenoptera: Anthophoridae), J. Kans. Entomol. Soc. 63, 414-419.

Kearns C.A., Inouye D.W. (1993) Techniques for pollination biologists, University Press of Colorado.

Klostermeyer E.C., Mech S.J., Rasmussen W.B. (1973) Sex and weight of Megachile rotundata (Hymenoptera: Megachilidae) progeny associated with provision weight, J. Kans. Entomol. Soc. 46, 536-548.

Michener C.D., Rettenmeyer C.W. (1956) The ethology of Andrena erythronii with comparative data on other species (Hymenoptera, Andrenidae), Univ. Kans. Sci. Bull. 37, 645-684.

Miliczky E.R. (1988) Observations on the bionomics of the bee Andrena (Tylandrena) erythrogaster Ashmead (Hymenoptera; Andrenidae) with notes on A. (Micrandrena) personata Robertson and A. (Holandrena) cressonii Robertson, Illinois Nat. Hist. Survey, Biol. Notes 130, 1-18.

Neff J.L., Simpson B.B. (1997) Nesting and foraging behavior of Andrena (Callandrena) rudbeckiae Robertson (Hymenoptera: Apoidea: Andrenidae) in Texas, J. Kans. Entomol. Soc. 70, 100-113.

O'Neil K.M. (1983) The significance of body size in territorial interactions of male beewolves (Hymenoptera, Sphecidae, Philanthus), Anim. Behav. 31, 404-411.

Paxton R.J., Giovanetti M., Andrietti F., Scamoni E., Scanni B. (1999) Mating in a primitively social bee, Andrena agilissima (Hymenoptera, Andrenidae), Ecol. Ethol. Evol. 11, 371-382.

Proctor M., Yeo P., Lack A. (1996) The natural history of pollination, Harper Collins Publ.

Pyke G.H. (1978) Optimal body size in bumblebees, Ecologia 34, 255-266.

Ramalho M., Imperatriz-Fonseca V.L., Giannini T.C. (1998) Within-colony size variation in the stingless bee Melipona quadrifasciata Lepeletier (Apidae, Hymenoptera), Apidologie 29, 221-228.

Roubik D.W. (1989) Ecology and natural history of tropical bees, Cambridge Univ. Press.

Roubik D.W., Buchmann S.L. (1984) Nectar selection by Melipona and Apis mellifera (Hymenoptera: Apidae) and the ecology of nectar intake by bee colonies in a tropical forest, Oecologia 61, 1-10.

Rust R.W., Vaissière B.E.,Westrich P. (2003) Pollinator biodiversity and floral resource use in Ecballium elaterium (Cucurbitaceae), a Mediterranean endemic, Apidologie 34, 29-42.

Schrader M.N., LaBerge W.E. (1978) The nest biology of the bees Andrena (Melandrena) regularis Malloch and Andrena (Melandrena) carlini Cockerell (Hymenoptera: Andrenidae), Illinois Nat. Hist. Survey, Biol. Notes No. 108.

Schönitzer K., Klinksik C. (1990) The ethology of the solitary bee Andrena nycthemera Imhoff, 1866 (Hymenoptera; Apoidea), Entomofauna 11, 377427.

Stone G.N. (1995) Female foraging responses to sexual harassment in the solitary bee Anthophora plumipes, Anim. Behav. 50, 405-412.

Stout J.C. (2000) Does size matter? Bumblebee behaviour and the pollination of Cytisus scoparius L. (Fabaceae), Apidologie 31, 129-139.

Sugiura N. (1991) Male territoriality and mating tactics in the wool-carder bee, Anthidium septemspinosum Lepeletier (Hymenoptera: Megachilidae), J. Ethol. 9, 95-103.

Visscher P.K., Danforth B.N. (1993) Biology of Calliopsis pugionis (Hymenoptera: Andrenidae): nesting, foraging and investment sex ratio, Ann. Entomol. Soc. Am. 86, 822-832.

Westrich P. (1989) Die Wildbienen Baden-Württembergs, Ulmer, Stuttgart.

Witt R. (1992) Zur Bionomie der Sandbiene Andrena barbilabris (Kirby, 1802) und ihrer Kuckucksbienen Nomada alboguttata (Herrich-Schäffer, 1839) und Sphecodes pellucidus (Smith, 1845), Drosera 92, 47-81. 